\title{
Planktonic community respiration in the East China Sea: importance of microbial consumption of organic carbon
}

\author{
Chung-Chi Chen ${ }^{\mathrm{a}, 1}$, Fuh-Kwo Shiah ${ }^{\mathrm{b}, *}$, Gwo-Ching Gong ${ }^{\mathrm{c}}$, Kuo-Ping Chiang ${ }^{\mathrm{d}}$ \\ ${ }^{a}$ National Center for Ocean Research, National Science Council, P.O. Box 23-13, Taipei, Taiwan 10617, ROC \\ ${ }^{\mathrm{b}}$ Institute of Oceanography, National Taiwan University, P.O. Box 23-13, Taipei, Taiwan 10617, ROC \\ ${ }^{\mathrm{c}}$ Department of Oceanography, National Taiwan Ocean University, Keelung 202-24, Taiwan, ROC \\ ${ }^{\mathrm{d}}$ Department of Fishery Science, National Taiwan Ocean University, Keelung 202-24, Taiwan, ROC
}

Accepted 18 December 2002

\begin{abstract}
Planktonic community respiration (PCR) rates were measured using the oxygen method in autumn 1998 in order to evaluate the respective roles played by microbes (heterotrophic bacteria and ciliates) in organic carbon consumption on the continental shelf of the East China Sea (ECS). For comparative purposes, the ECS shelf was divided into mesotrophic $\left(\left[\mathrm{NO}_{3}^{-}\right]>0.3 \mu \mathrm{M}\right)$ and oligotrophic $\left(\left[\mathrm{NO}_{3}^{-}\right] \leqslant 0.3 \mu \mathrm{M}\right)$ systems. Bacterial biomass $\left(23.4 \pm 28.4 \mathrm{mg} \mathrm{C} \mathrm{m}^{-3}\right)$ and production $\left(4.9 \pm 6.8 \mathrm{mg} \mathrm{C} \mathrm{m}^{-3} \mathrm{~d}^{-1}\right)$ as well as particulate organic carbon concentrations $\left(129.3 \pm 40.4 \mathrm{mg} \mathrm{C} \mathrm{m}^{-3}\right)$ were significantly higher in the mesotrophic system, while protozoa $\left(95.6 \pm 74.9 \mathrm{mg} \mathrm{C} \mathrm{m}^{-3}\right)$ were more abundant in the oligotrophic system. PCR rates ranged from 127.6 to $4728.6 \mathrm{mg} \mathrm{C} \mathrm{m}^{-2} \mathrm{~d}^{-1}$, and the rates were either linearly related to protozoan biomass or multiply regressed with both bacterial and protozoan biomass. Further analysis showed that PCR were dominated by distinct microbial components in different trophic systems, with bacteria and protozoa contributing $72 \%$ and $85 \%$ of PCR in meso- and oligotrophic systems, respectively. The low primary production to PCR ratio $(0.33 \pm 0.30)$ suggests that the ECS was net heterotrophic during the study period. Allochthonous supplies of organic carbon, in addition to in situ production, are required to support these high respiration rates. Riverine inputs and/or resuspension from superficial sediments are potential sources of this allochthonous organic carbon.

(C) 2003 Elsevier Science Ltd. All rights reserved.
\end{abstract}

\section{Introduction}

The continental shelf is a boundary zone between the land-ocean margins. Although the continental shelf represents less than $20 \%$ of the world's oceanic area, it's high nutrient input from

\footnotetext{
*Corresponding author. Fax: + 011-886-2-369-5746.

E-mail address: fkshiah@ccms.ntu.edu.tw (F.-K. Shiah).

${ }^{1}$ Now at: Deparment of Biology, National Taiwan Normal University, 88, Sec. 4, Ting-Chou Rd. Taipei 116, Taiwan, ROC
}

riverine run-off has made it one of the most productive areas in the world (Liu et al., 2000a). Continental shelf primary production total could be as important as that in the ocean interior (Walsh, 1991). Even though there is a debate as to whether the continental shelf is primarily a carbon source or sink, the carbon flow in this area to global carbon flux is important. (Liu et al., 2000a). Understanding the carbon fluxes and cycling processes in the shelf ecosystem is therefore a key step toward estimating the global carbon 
budget precisely (Siegenthaler and Sarmiento, 1993).

The East China Sea (ECS) is one of the largest continental shelves in the world. Varieties of water masses have been contributed to, and complicate, this shelf ecosystem, including a large amount of riverine run-off from the west, intrusion and upwelling of the Kuroshio surface and subsurface waters from the east, the Yellow Sea waters from the northern boundary, and the Taiwan Strait waters from the south (Wong et al., 2000). Significant amounts of allochthonous organic carbon and inorganic nutrients have been supplied to the ECS from riverine run-off and/or from the upwelling Kuroshio waters (Cauwet and Mackenzie, 1993; Chen and Wang, 1996; Wong et al., 1998; Liu et al., 2000b). Enhanced by abundant substrate, high biological productivity with seasonal and spatial variation has been observed in the ECS (Guo, 1991; Gong et al., 2000; Shiah et al., 2000a).

High primary production tends to enhance the biological pump and draws down the dissolved $\mathrm{CO}_{2}$ concentration. Significant $\mathrm{CO}_{2}$ sink (ca. 1.2$2.9 \mathrm{~mol} \mathrm{~m}^{-2} \mathrm{yr}^{-1}$ ) was indeed observed in the ECS shelf using air-sea difference of $f \mathrm{CO}_{2}$ (Peng et al., 1999; Tsunogai et al., 1999; Wang et al., 2000). However, large uncertainty existed when trying to explore carbon cycling process, especially concerning how biological production and remineralization of organic matter contribute to this process. Based on bacterial production, Shiah et al. (2000a) estimated that bacteria might consume carbon equivalent to all the in situ particulate primary productivity in the ECS shelf. In addition, other planktonic communities (i.e. protozoa and zooplankton) also may consume a large fraction of the organic carbon, which in turn will reduce the carbon deposition (Rowe et al., 1986; Kemp et al., 1994). In all cases, it is suggested that biological activity plays an important role in carbon cycling processes in this shelf ecosystem.

The objective of this study, which is part of the Kuroshio edge exchange processes (KEEP) program, is to examine the role biological activity plays in carbon cycling within the ECS. Biological carbon productions have been reported previously; however, organic carbon consumption through biological activities has never been estimated in this shelf ecosystem (Gong et al., 1999, 2000). To explore spatial variation, plankton community autumn respiration was measured in the ECS. Respiration was also analyzed with biological variables (i.e. Chlorophyll $a(\mathrm{Chl} a)$ and biomass of bacteria and protozoa) to discriminate how carbon consumption was attributed to various components. Furthermore, the relative importance of components (bacteria and protozoa) contributing to respiration was estimated to understand their roles in different designated trophic ecosystems. Finally, biological carbon production and consumption (respiration) were compared to delineate the role played by biological activity on carbon balance.

\section{Materials and methods}

\subsection{Study area and sampling}

Samples were collected on board R/V Ocean Researcher I between 29 October and 5 November 1998, and a total of 33 stations were occupied (Fig. 1). Using Teflon coated Go-Flo bottles

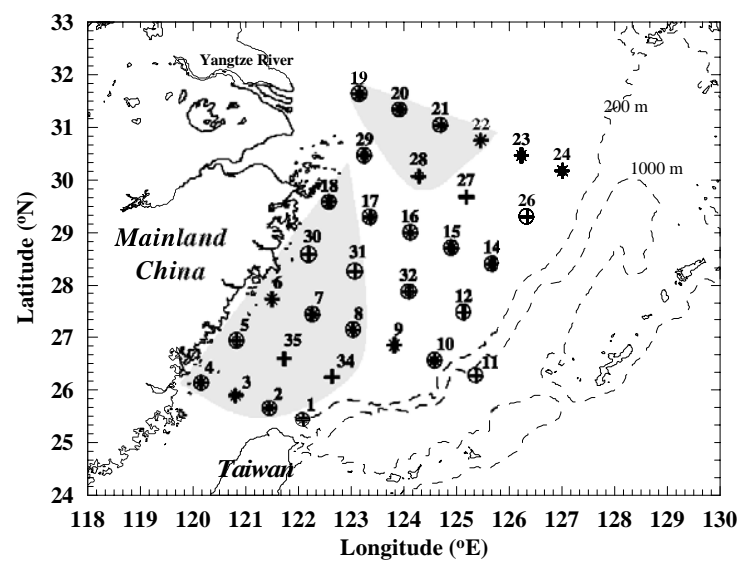

Fig. 1. Map of stations (+) in the East China Sea with station number above the mark. Stations conducting protozoa sampling $(x)$, community respiration incubation $(O)$, and primary production incubation $(\square)$ are also indicated. Stations with high surface nitrate concentrations $(>0.3 \mu \mathrm{M})$ are shaded and defined as mesotrophic, and low surface nitrate concentrations $(\leqslant 0.3 \mu \mathrm{M})$ are classified as oligotrophic. Bottom depth contours (dashed lines; 200 and $1000 \mathrm{~m}$ ) are also shown. 
(201, General Oceanics Inc., USA) mounted on a General Oceanic rosette assembly, seawater at each station was sampled at 6-10 water depths, at depth intervals of 3-50 $\mathrm{m}$ depending on the depth of each station. Subsamples were taken immediately for further analyses (i.e. nutrients, particulate organic carbon, Chl $a$, and bacterial and protozoan abundance) and on-board incubations (primary and bacterial production, and plankton community respiration).

\subsection{Hydrographic and optical measurements}

Temperature, salinity and density were recorded throughout the water column with a SeaBird CTD (SBE 9/11 puls, SBE Inc., USA). Photosynthetically active radiation (PAR) was measured all through the water column with a biospherical log quantum scalar irradiance sensor ( $4 \pi$; QSP-200L) attached to the rosette frame. Total downwelling scalar irradiance above the sea surface was measured continuously with a separate biospherical quantum scalar irradiance system (QSP 160), equipped with a surface $2 \pi$ steradian hemispherical scalar irradiance sensor (QSR-240). The depth of the euphotic zone $\left(Z_{\mathrm{E}}\right)$ was taken as the depth of $1 \%$ surface light penetration.

\subsection{Nutrients, Chl a and particulate organic carbon}

Water subsamples for nutrient analyses were collected from every sampling depth with 100-ml polypropylene bottles and frozen immediately with liquid nitrogen. A custom-made flow injection analyzer was used for nitrate analysis (Gong, 1992). Chl $a$ concentration was measured with a Sea Tech fluorometer attached to the SeaBird CTD for a continuous profile of in vivo fluorescence, with data calibrated by in vitro fluorometery (Turner Design 10-AU-005) following acetone extraction (Strickland and Parsons, 1972). At selected stations, samples for particulate organic carbon (POC) were filtered through a Whatman 25-mm GF/F filter, wrapped in aluminum foil and then stored at $4{ }^{\circ} \mathrm{C}$. Both filter and aluminum foil were pre-combusted at $550^{\circ} \mathrm{C}$ for an hour. After drying and acid-fuming, POC samples were measured by combustion method using a
HORIBA EMIA-510 analyzer (Shiah et al., 2000b).

The trapezoidal method was used to estimate integrated $\mathrm{Chl} a$ over $Z_{\mathrm{E}}$, and this method was also applied to calculate integrated values for POC, bacterial biomass and production, protozoan biomass, primary production, and plankton community respiration. Mean $\mathrm{Chl} a$ concentration over $Z_{\mathrm{E}}$ was estimated from the integrated value divided by $Z_{\mathrm{E}}$, and this calculation also was adopted with other variables.

\subsection{Bacterial abundance and production}

Bacterial abundance and production were measured at all stations, and duplicate samples were taken from several depths within $Z_{\mathrm{E}}$. Bacterial abundance was determined by acridine orange epifluorescence microscopy (Hobbie et al., 1977). To convert to carbon units, bacterial abundance was used with a conversion factor of $20 \times 10^{-15} \mathrm{gC}$ cell $^{-1}$ (Lee and Fuhrman, 1987). Bacterial production was estimated by ${ }^{3} \mathrm{H}$-thymidine incorporation with a thymidine conversion factor of $1.18 \times 10^{18}$ cell mole $^{-1}$ (Cho and Azam, 1980; Fuhrman and Azam, 1982; Shiah et al., 1999).

\subsection{Protozoan abundance}

Samples for protozoan abundance were collected at several depths within $Z_{\mathrm{E}}$ from 20 stations (Fig. 1). Samples were fixed with neutralized formalin ( $2 \%$ final concentration) and then stored in the dark at $4{ }^{\circ} \mathrm{C}$ for subsequent microscopic examination. Samples were identified and counted using an inverted epifluorescence microscope (Nikon-Tmd 300 ) at $200 \times$ or $400 \times$. Cellular carbon was calculated from cell volume using a conversion factor of $0.14 \mathrm{pgC}^{-3} \mathrm{~m}^{-3}$ (Putt and Stoecker, 1989).

\subsection{Primary productivity}

Primary production was measured by the ${ }^{14} \mathrm{C}$ assimilated method at 12 stations (Fig. 1; Parsons et al., 1984; Gong et al., 1999). Water samples were collected from 6 depths within $Z_{\mathrm{E}}$. Samples were pre-screened through $200-\mu \mathrm{m}$ woven mesh 
(Spectrum), and inoculated with $\mathrm{H}^{14} \mathrm{CO}_{3}^{-}$(final conc. $10 \mu \mathrm{Ci} \mathrm{m}^{-1}$ ) in $250-\mathrm{ml}$ clean polycarbonate bottle (Nalgene). Samples were incubated on board for $2-4 \mathrm{~h}$ in chambers filled with running surface seawater and illuminated by fluorescent bulbs with a light intensity corresponding to the in situ irradiance level. Following each incubation, samples were filtered on GF/F filters (Whatman, $25 \mathrm{~mm}$ ) and acidified with $0.5 \mathrm{ml} 2 \mathrm{~N} \mathrm{HCl}$ for overnight. After immersion in $10 \mathrm{ml}$ of scintillation cocktail (Ultima Gold, Packard), total activity on the filter was counted in a liquid scintillation counter (Packard 1600). To estimate the euphotic zone-integrated primary production (IP) at stations where incubation was not performed, the following empirical function was used:

$[\mathrm{IP}]=2.512 *\left[C_{\mathrm{S}} * P_{\mathrm{opt}}^{\mathrm{B}} * K_{\mathrm{d}}^{-1}\right]^{0.957}$,

where $C_{\mathrm{S}}, P_{\mathrm{opt}}^{\mathrm{B}}$ and $K_{\mathrm{d}}$ were the surface Chl $a$ concentration, optimal photosynthetic efficiency, and mean attenuation coefficient within $Z_{\mathrm{E}}$, respectively (see Gong and Liu, 2003).

\subsection{Plankton community respiration}

Plankton community respiration was measured as dissolved oxygen $\left(\mathrm{O}_{2}\right)$ decreasing in dark incubation at 22 stations (Fig. 1; Gaarder and Grann, 1927). Triplicate samples were taken for either initial or treatment from 2 to 6 discrete depths within $Z_{\mathrm{E}}$. Samples were siphoned into 60$\mathrm{ml}$ biological oxygen-demand bottles (Cat. No. 227494-00, Wheaton, Millville, NJ, USA). The treatment involved bottles incubating for $12 \mathrm{~h}$ in a dark chamber filled with running surface seawater and maximum temperature changes less than $1.33 \pm 0.85^{\circ} \mathrm{C}$ (mean $\left.\pm \mathrm{SD}\right)$ during each incubation. Temperature differences between top and bottom of $Z_{\mathrm{E}}$ in all incubation stations were also small, with mean $\pm \mathrm{SD}$ values of $0.20 \pm 0.56^{\circ} \mathrm{C}$. Concentration of $\mathrm{O}_{2}$ was measured by direct spectrophotometry method with precision of $0.5 \mu \mathrm{M}$ (Pai et al., 1993). The difference in $\mathrm{O}_{2}$ concentration between initial and dark treatment was used to compute plankton community respiration. Since temperature changes were insignificant between incubation chambers and in situ environments, the rate was not corrected for temperature effects. To convert respiration from oxygen to carbon units, a respiration quotation (RQ) of 1 was applied (Parsons et al., 1984; Hopkinson, 1985).

\section{Results}

\subsection{Hydrography in the East China Sea}

Surface temperature (SST) in the ECS increased from the inner shelf $\left(21^{\circ} \mathrm{C}\right)$ to the slope $\left(27^{\circ} \mathrm{C}\right)$, with isotherms parallel to the coastal shoreline (Fig. 2a). Surface salinity contours also showed a similar trend, with values ranging from 27.48 to 34.40 psu (Fig. 2b). Nitrate concentrations in the surface water were in the range $0-24.3 \mu \mathrm{M}$, with high nutrient concentration along the inner shelf and in the northwest of the ECS, near the Yangtze River (Changjiang) estuary (Fig. 2c). For a more systematic understanding of this shelf ecosystem, the ECS was categorized into mesotrophic and oligotrophic systems by surface nitrate concentration, $>0.3$ and $\leqslant 0.3 \mu \mathrm{M}$, respectively (Fig. 2c).

\subsection{Biological variables in the ECS}

To understand spatial variation of different variables in the ECS, biological variables (i.e. biomass and rates) were compared between mesotrophic and oligotrophic systems. In the ECS, mixed-layer depth (MLD) ranged from 4 to $69 \mathrm{~m}$, with a mean $\pm \mathrm{SD}$ value of $39.8 \pm 21.3 \mathrm{~m}$ (Table 1). On average, MLD was significantly shallower in the mesotrophic than in the oligotrophic systems, with mean $\pm \mathrm{SD}$ values of $33.9 \pm 22.2 \mathrm{~m}$ and $49.7 \pm 15.4 \mathrm{~m}$, respectively $(p=0.01)$. Euphotic depth $\left(Z_{\mathrm{E}}\right)$ varied from 3 to $66 \mathrm{~m}$ in the ECS, with a mean \pm SD value of $37.7 \pm 19.0 \mathrm{~m}$ (Table 1). Similar to the MLD, $Z_{\mathrm{E}}$ was also shallower in the mesotrophic than in the oligotrophic systems, with mean $\pm \mathrm{SD}$ values of $27.3 \pm 18.9$ and $49.5 \pm 10.5 \mathrm{~m}$, respectively $(p<0.01)$. There was however no difference observed between MLD and $Z_{\mathrm{E}}$ in the ECS $(p=0.68)$. Since most of biological variables were measured within $Z_{\mathrm{E}}$, both biomass and rate were 

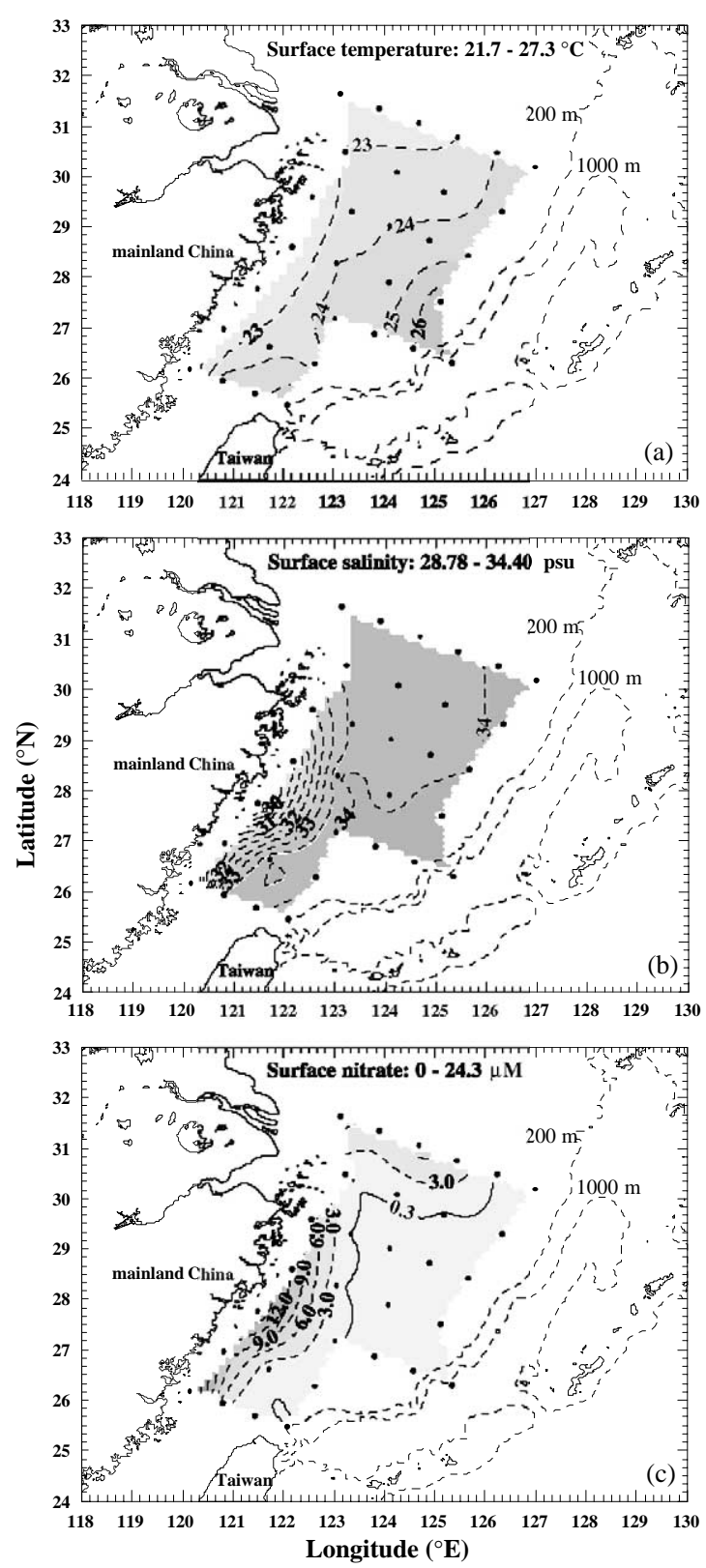

Fig. 2. Contour plots for surface $(2 \mathrm{~m})$ values of temperature, salinity, and nitrate concentration in the East China Sea, with contour intervals of $1^{\circ} \mathrm{C}, 0.5 \mathrm{psu}$, and $3 \mu \mathrm{M}$, respectively.

therefore integrated over $Z_{\mathrm{E}}$, instead of MLD, for further comparison.

Integrated $\mathrm{Chl} a$ values in mesotrophic and oligotrophic systems were in the ranges $1.5-70.1$ and $11.7-74.4 \mathrm{mg} \mathrm{Chl} \mathrm{m}^{-2}$, respectively (Table 1). Even though mean values of integrated Chl $a$ were slightly lower in mesotrophic $(28.1 \pm$ $20.4 \mathrm{mg} \mathrm{Chl} \mathrm{m}^{-2}$ ) than in oligotrophic systems $\left(40.3 \pm 19.6 \mathrm{mg} \mathrm{Chl} \mathrm{m}^{-2}\right)$, it was not statistically significant $(p=0.10)$. Integrated values of primary production in mesotrophic and oligotrophic systems were in the ranges 16-797 and 106$854 \mathrm{mg} \mathrm{C} \mathrm{m}^{-2} \mathrm{~d}^{-1}$, respectively. No significant difference $(p=0.14)$ in integrated primary production was evident between the meso- and oligotrophic systems, with mean $\pm \mathrm{SD}$ values of $283 \pm 229$ and $407 \pm 231 \mathrm{mg} \mathrm{C} \mathrm{m}^{-2} \mathrm{~d}^{-1}$, respectively. Significant linear regression, however was evident between the integrated values of primary production and Chl $a$, with slope and $r^{2}$ values of linear regression of 9.8 and 0.75 , respectively $(p<0.01)$.

Integrated bacterial biomass was relatively constant and ranged from 222.3 to $426.2 \mathrm{mg} \mathrm{C} \mathrm{m}^{-2}$ in the ECS (Table 1). There was no statistical difference $(p=0.60)$ in mean values of integrated bacterial biomass between mesotrophic $\left(295.3 \pm 53.1 \mathrm{mg} \mathrm{C} \mathrm{m}^{-2}\right)$ and oligotrophic systems $\left(305.8 \pm 58.2 \mathrm{~m} \mathrm{C} \mathrm{m}^{-2}\right)$, but, mean bacterial biomass $\left(\mathrm{mg} \mathrm{C} \mathrm{m}^{-3}\right)$ over $Z_{\mathrm{E}}$ was significantly higher $(p<0.001)$ in the mesotrophic $(23.4 \pm$ $\left.28.4 \mathrm{mg} \mathrm{C} \mathrm{m}^{-3}\right)$ than in the oligotrophic systems $\left(6.9 \pm 3.8 \mathrm{mg} \mathrm{C} \mathrm{m}^{-3}\right)$. Integrated bacterial productivity between the systems was not statistically $(p=0.06)$, although mean values were larger in mesotrophic $\left(55.9 \pm 16.7 \mathrm{mg} \mathrm{C} \mathrm{m}^{-2} \mathrm{~d}^{-1}\right)$ than in oligotrophic $\left(45.2 \pm 14.2 \mathrm{mg} \mathrm{C} \mathrm{m}^{-2} \mathrm{~d}^{-1}\right)$ systems. Similar spatial patterns were observed between integrated values of bacterial productivity and biomass in the ECS (data not shown). Therefore, a significant relationship between integrated bacterial biomass and productivity was indeed evident, with slope and $r^{2}$ values of linear regression of 0.21 and 0.48 , respectively $(n=32, p<0.01)$. Similar to bacterial biomass, a significant difference also was found in mean bacterial production over $Z_{\mathrm{E}}$ between different systems $(p<0.01)$, i.e. bacterial production was higher in mesotrophic $(4.9 \pm$ $\left.6.8 \mathrm{mg} \mathrm{C} \mathrm{m}^{-3} \mathrm{~d}^{-1}\right)$ than in oligotrophic systems $\left(1.0 \pm 0.5 \mathrm{mg} \mathrm{C} \mathrm{m}^{-3} \mathrm{~d}^{-1}\right)$. A significant relationship also was observed between mean values of bacterial biomass and production over $Z_{\mathrm{E}}$, with 
Table 1

Different variables in the mesotrophic (Meso) and oligotrophic (Oligo) systems in the ECS including: water column depth (m), mixedlayer depth (MLD; m), euphotic depth $\left(Z_{\mathrm{E}} ; \mathrm{m}\right)$, and integrated values of chlorophyll $a\left(\mathrm{Chl} a ; \mathrm{mg} \mathrm{Chl} \mathrm{m}^{-2}\right)$, primary productivity (PP; $\mathrm{mg} \mathrm{C} \mathrm{m}^{-2} \mathrm{~d}^{-1}$ ), bacterial biomass (BB; $\mathrm{mg} \mathrm{C} \mathrm{m}^{-2}$ ), protozoan biomass (Prot; $\mathrm{mg} \mathrm{C} \mathrm{m}^{-2}$ ), particulate organic carbon $\left(\mathrm{POC} ; \mathrm{mg} \mathrm{Cm}^{-2}\right.$ ), and planktonic community respiration (PCR; $\mathrm{mg} \mathrm{Cm}^{-2} \mathrm{~d}^{-1}$ ) over $Z_{\mathrm{E}}$ at different stations (Sts). MLD was based on a 0.125 unit potential density criterion (Levitus, 1982). $E_{\mathrm{Z}}$ was assumed at depth where light intensity $\geqslant 1 \%$ of surface light intensity

\begin{tabular}{|c|c|c|c|c|c|c|c|c|c|c|}
\hline System & Sts & Depth & MLD & $Z_{\mathrm{E}}$ & Chl $a$ & PP & BB & Prot & POC & PCR \\
\hline Meso & 2 & 82 & $14^{\mathrm{a}}$ & 36 & 27.1 & 248 & 222.3 & 283.4 & - & 190.6 \\
\hline Meso & 3 & 62 & $41^{\mathrm{a}}$ & 26 & 10.3 & 94 & 246.2 & 10.0 & - & - \\
\hline Meso & 4 & 31 & $7^{\mathrm{a}}$ & 3 & 1.5 & 16 & 355.2 & 0.5 & - & 248.8 \\
\hline Meso & 5 & 31 & $8^{a}$ & 6 & 5.1 & 86 & 301.3 & - & 559.2 & 310.8 \\
\hline Meso & 6 & 26 & $7^{\mathrm{a}}$ & 6 & 4.1 & 38 & 285.8 & 5.2 & - & - \\
\hline Meso & 7 & 77 & $66^{\mathrm{a}}$ & 50 & 41.8 & 797 & 292.9 & 511.8 & - & 1100.8 \\
\hline Meso & 8 & 97 & $50^{\mathrm{a}}$ & 48 & 37.4 & 434 & 267.2 & 1374.9 & - & 2486.1 \\
\hline Meso & 18 & 26 & $14^{\mathrm{a}}$ & 8 & 11.7 & 107 & 270.2 & 38.6 & - & 306.5 \\
\hline Meso & 19 & 26 & $26^{\mathrm{a}}$ & 9 & 11.1 & 73 & 222.3 & 37.2 & 1586.5 & 127.6 \\
\hline Meso & 20 & 44 & $4^{\mathrm{a}}$ & 26 & 56.7 & 514 & 372.3 & 327.5 & 4150.3 & 620.9 \\
\hline Meso & 21 & 40 & $40^{\mathrm{a}}$ & 23 & 70.1 & 640 & 246.2 & 504.6 & 3689.6 & 897.6 \\
\hline Meso & 22 & 51 & $51^{\mathrm{a}}$ & 15 & 15.9 & 145 & 354.3 & 91.3 & 1521.5 & - \\
\hline Meso & 28 & 51 & $51^{\mathrm{a}}$ & 28 & 31.5 & 213 & 401.1 & - & 2376.0 & - \\
\hline Meso & 30 & 31 & $12^{\mathrm{a}}$ & 19 & 21.8 & 204 & 305.1 & - & - & 839.3 \\
\hline Meso & 31 & 72 & $62^{\mathrm{a}}$ & 56 & 37.6 & 345 & 270.0 & - & - & 2218.2 \\
\hline Meso & 34 & 91 & $15^{\mathrm{a}}$ & 62 & 39.0 & 354 & 265.8 & - & - & - \\
\hline Meso & 35 & 72 & $58^{\mathrm{a}}$ & 42 & 55.2 & 501 & 342.2 & - & - & - \\
\hline Oligo & 1 & 201 & $6^{\mathrm{a}}$ & 22 & 30.1 & 623 & 426.2 & 304.3 & 1903.4 & 1011.8 \\
\hline Oligo & 9 & 107 & $39^{\mathrm{a}}$ & 44 & 32.2 & 410 & 294.2 & 3529.0 & 3629.2 & - \\
\hline Oligo & 10 & 140 & $50^{\mathrm{a}}$ & 52 & 27.9 & 215 & 241.0 & 1687.5 & 3911.3 & 1282.3 \\
\hline Oligo & 11 & 151 & $35^{\mathrm{a}}$ & 52 & 11.7 & 107 & 317.0 & - & - & 623.9 \\
\hline Oligo & 12 & 91 & $69^{\mathrm{a}}$ & 66 & 18.0 & 165 & 234.8 & - & - & 2219.2 \\
\hline Oligo & 14 & 92 & $64^{\mathrm{a}}$ & 51 & 35.9 & 308 & 339.0 & 7552.5 & 4235.3 & 4728.6 \\
\hline Oligo & 15 & 71 & $65^{\mathrm{a}}$ & 43 & 62.6 & 854 & 348.2 & 9222.7 & - & 2914.9 \\
\hline Oligo & 16 & 61 & $53^{\mathrm{a}}$ & 49 & 66.4 & 615 & 373.8 & 9894.4 & - & 3697.5 \\
\hline Oligo & 17 & 61 & $57^{\mathrm{a}}$ & 45 & 74.4 & 678 & 341.0 & 3239.6 & - & 1186.7 \\
\hline Oligo & 23 & 66 & $48^{\mathrm{a}}$ & 53 & 51.2 & 573 & 318.9 & 3692.5 & 4248.5 & - \\
\hline Oligo & 24 & 81 & $53^{\mathrm{a}}$ & 62 & 30.0 & 106 & 300.2 & 1728.4 & 3679.6 & - \\
\hline Oligo & 26 & 92 & $49^{\mathrm{a}}$ & 47 & 20.9 & 186 & 289.5 & - & - & 396.4 \\
\hline Oligo & 27 & 80 & $54^{\mathrm{a}}$ & 54 & 51.3 & 505 & 222.3 & - & - & - \\
\hline Oligo & 29 & 51 & $43^{\mathrm{a}}$ & 41 & 63.5 & 451 & 318.8 & - & 3916.4 & 1267.3 \\
\hline Oligo & 32 & 91 & $61^{\mathrm{a}}$ & 61 & 28.9 & 315 & 222.3 & - & 4177.1 & 3076.0 \\
\hline
\end{tabular}

${ }^{\mathrm{a}}$ Where MLD $\geqslant 70 \%$ of water column depth; $(-)$ no data measured.

slope and $r^{2}$ values of linear regression of 0.24 and 0.99 , respectively $(n=32, p<0.01)$.

In this study, protozoan abundance was mostly dominated by ciliates (either hetero- or mixotrophes), which accounted for about $90 \%$ of the total abundance, while a small amount was composed by tintinids. Integrated protozoan biomass in the mesotrophic system was fairly low $\left(289.5 \pm 410.3 \mathrm{mg} \mathrm{C} \mathrm{m}^{-2}\right)$, and higher biomass was found in the oligotrophic system, ranging from 304.3 to $9894.4 \mathrm{mg} \mathrm{C} \mathrm{m}^{-2}$ with a mean $\pm \mathrm{SD}$ value of $4539.0 \pm 3483.7 \mathrm{mg} \mathrm{C} \mathrm{m}^{-2}$ (Table 1). The difference in integrated protozoan biomass between systems was statistically significant $(p<0.01)$. A similar pattern also was observed in mean protozoan biomass over $Z_{\mathrm{E}}$, i.e. mean protozoan biomass was significantly smaller in mesotrophic $\left(8.9 \pm 9.1 \mathrm{mg} \mathrm{C} \mathrm{m}^{-3}\right)$ than in oligotrophic systems $\left(95.6 \pm 74.9 \mathrm{mg} \mathrm{C} \mathrm{m}^{-3} ; p<0.01\right)$.

Integrated particulate organic carbon (POC) was significantly higher $(p<0.05)$ in oligotrophic than in mesotrophic systems, with mean $\pm \mathrm{SD}$ 
values of $3712.6 \pm 768.9 \mathrm{mg} \mathrm{Cm}^{-2}$ and $2313.9 \pm 1378.8 \mathrm{mg} \mathrm{C} \mathrm{m}^{-2}$, respectively (Table 1 ). An inverse pattern, however, was, found in mean POC concentrations (i.e., $\mathrm{mg} \mathrm{C} \mathrm{m}^{-3}$ ) over $Z_{\mathrm{E}}$ between systems, i.e. mean POC concentrations were significantly $(p<0.01)$ lower in oligotrophic $\left(81.4 \pm 13.0 \mathrm{mg} \mathrm{C} \mathrm{m}^{-3}\right)$ than in mesotrophic systems $\left(129.3 \pm 40.4 \mathrm{mg} \mathrm{C} \mathrm{m}^{-3}\right)$. To understand how POC stock related to biological variables, integrated POC was analyzed to correlate with measured biological parameters. Among all the analyses, integrated POC was multiply regressed with integrated stocks of Chl $a$ and protozoa $\left(r^{2}=0.73, p=0.01\right)$.

\subsection{Contribution of different components to planktonic community respiration}

To understand how planktonic community respiration (PCR) contributed by different components, linear regression was used to analyze relationships between mean PCR $\left(\mathrm{mg} \mathrm{C} \mathrm{m}^{-3} \mathrm{~d}^{-1}\right)$ versus mean biomasses $\left(\mathrm{mg} \mathrm{C} \mathrm{m}^{-3}\right)$ of bacterioplankton, phytoplankton and protozoa, and mean bacterial production as well as primary production over $Z_{\mathrm{E}}$. Of all the analyses, PCR was only significantly related to protozoan biomass (Fig. 3a; $\left.r^{2}=0.38, p<0.05\right)$. Even though there was a weak relation between PCR and bacterial biomass (or bacterial production), it was not statistically significant (Fig. $3 b ; r^{2}=0.15, p=0.08$ ). No significant relationship was evident between PCR and phytoplankton biomass.

Planktonic community respiration represents the summation of carbon consumption by all planktonic communities. To see how PCR correlated with planktonic communities, forward stepwise multiple linear regression was used to analyze the relationship between PCR versus biomass of phytoplankton, bacteria and protozoa. A significant relationship was found for PCR versus both biomass of bacteria and protozoa $\left(r^{2}=0.70\right.$, $p=0.001)$, and it can be expressed as follows:

$\mathrm{PCR}=0.54 * B_{\mathrm{B}}+0.29 * B_{\mathrm{P}}+17.23$,

where PCR, $B_{\mathrm{B}}$, and $B_{\mathrm{P}}$ are mean values of PCR, bacterial biomass, and protozoan biomass over $Z_{\mathrm{E}}$, respectively. Inclusion of phytoplankton
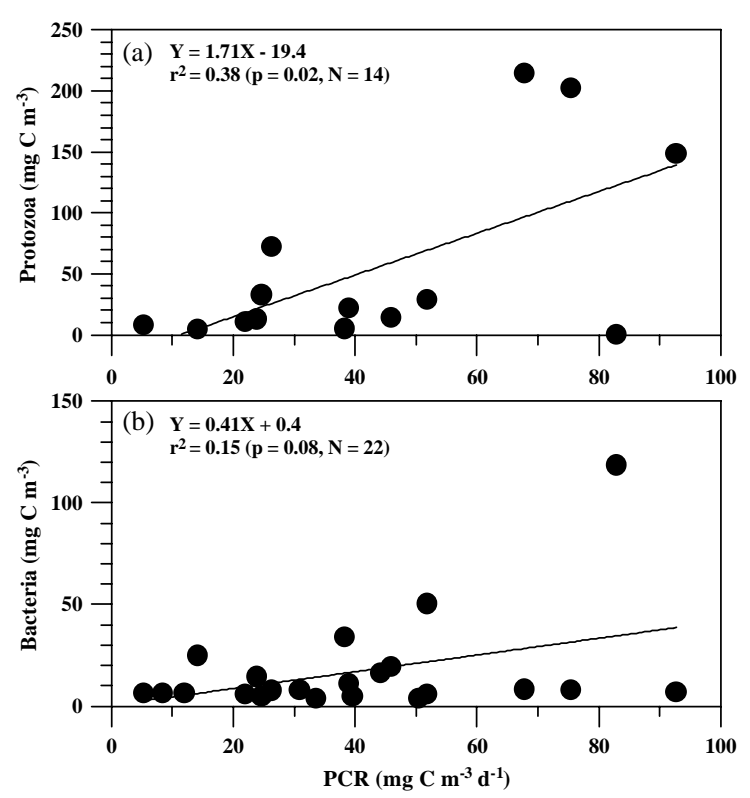

Fig. 3. Relationship between planktonic community respiration ( $\mathrm{mg} \mathrm{Cm}^{-3} \mathrm{~d}^{-1}$; PCR) and biomass of (a) protozoa, and (b) bacteria in the euphotic zone. Slopes, $r^{2}$ and $p$ values of linear regression also were shown.

biomass in this analysis, however, did not improve the relationship.

\subsection{Respiration and $P / R$ ratio}

The contour of integrated PCR $\left(\mathrm{mg} \mathrm{C} \mathrm{m}^{-2} \mathrm{~d}^{-1}\right)$ demonstrated how organic carbon was consumed in autumn in the ECS ecosystem. Integrated PCR in the ECS ranged from 127.6 to $4728.6 \mathrm{mg}$ $\mathrm{C} \mathrm{m}^{-2} \mathrm{~d}^{-1}$ (i.e., $5.3-92.7 \mathrm{mg} \mathrm{C} \mathrm{m}^{-3} \mathrm{~d}^{-1}$ ), with a mean \pm SD value of $1443.3 \pm 1269.2 \mathrm{mg} \mathrm{C} \mathrm{m}^{-2} \mathrm{~d}^{-1}$ (Fig. 4). Significant difference was evident in integrated PCR between trophic systems $(p<0.05)$, and the rates were higher in oligotrophic than in mesotrophic systems, with mean $( \pm S D)$ values of $2036.8( \pm 1396.8)$ and 849.7 $( \pm 810.6) \mathrm{mg} \mathrm{C} \mathrm{m}^{-2} \mathrm{~d}^{-1}$, respectively. There was, however, no difference in mean values of PCR (i.e., $\mathrm{mg} \mathrm{Cm}^{-3} \mathrm{~d}^{-1}$ ) over $Z_{\mathrm{E}}$ between these two systems $(p=0.16)$. Higher integrated PCR values were found at stations located in both mesotrophic (i.e., Sts. 8 and 31) and oligotrophic (i.e., Sts. 12, 14, 15, 16 and 32) systems (Fig. 4). Respiration at 


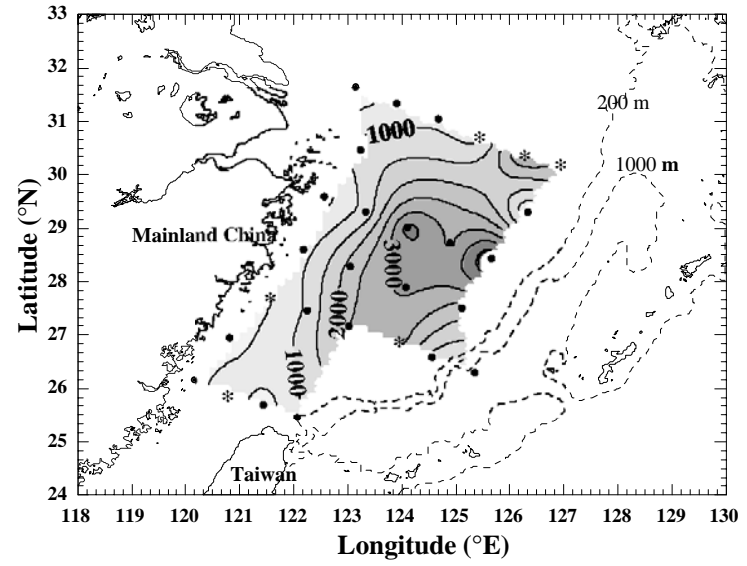

Fig. 4. Contour plot of integrated values of planktonic community respiration $\left(\mathrm{mg} \mathrm{C} \mathrm{m}^{-2} \mathrm{~d}^{-1}\right)$ in the euphotic zone in the East China Sea. Stations with respiration incubation were labeled with solid $(\bullet)$ circles, and where marked with asterisk (*) respiration was derived from Eq. (1) (see text for details). Respiration quotient (RQ) of 1 was used to convert oxygen to carbon units.

those high rate stations was in the range of $2218.2-$ $4728.6 \mathrm{mg} \mathrm{C} \mathrm{m}^{-2} \mathrm{~d}^{-1}$, and the rates were relatively low at all other stations (Fig. 4).

The ratio of primary production to respiration $(P / R$ ratio) has been used to examine whether an ecosystem is either autotrophic (i.e., $P / R$ ratio $>1$ ) or heterotrophic (i.e., $P / R$ ratio $<1$ ). In this study, ratio of integrated primary production $\left(\mathrm{mg} \mathrm{C} \mathrm{m}^{-2} \mathrm{~d}^{-1}\right)$ to integrated respiration $\left(\mathrm{mg} \mathrm{C} \mathrm{m}{ }^{-2} \mathrm{~d}^{-1}\right)$ was used to explore carbon utilization between production and consumption in the ECS. Respiration in the water column below $Z_{\mathrm{E}}$ and from sediment was not included in this estimation; therefore, the estimated $P / R$ ratio will be larger than the theoretical $P / R$ value. In the ECS, the $P / R$ ratio ranged between 0.04 and 1.30 , with a mean $\pm \mathrm{SD}$ value of $0.33 \pm 0.30$. The $P / R$ ratio was less than 1 at all stations except St. 2 (Fig. 5). Even though the mean $P / R$ ratio was slightly higher in mesotrophic $(0.42 \pm 0.34)$ than in oligotrophic systems $(0.24 \pm 0.19)$, it was not statistically significantly $(p=0.12)$. To explore how primary production affect $P / R$ ratio, the ratios were plotted against integrated primary productivity $\left(\mathrm{mg} \mathrm{C} \mathrm{m}^{-2} \mathrm{~d}^{-1}\right)$. No significant linear relationship was found between ratio of $P / R$ and

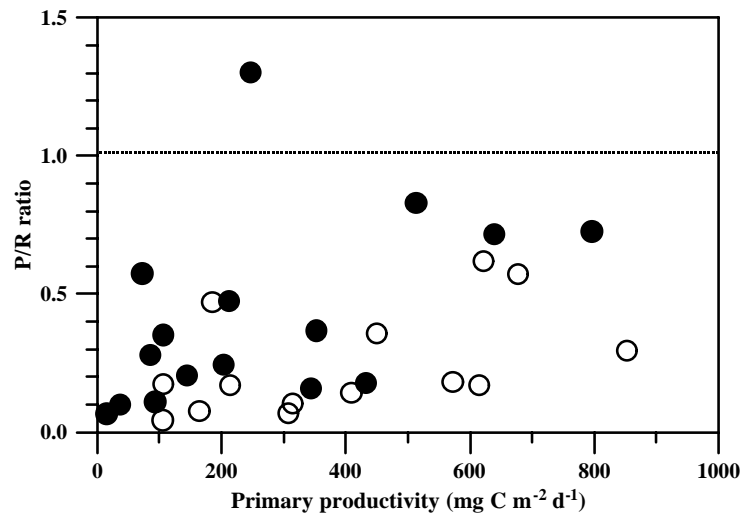

Fig. 5. Ratio of primary production $\left(\mathrm{mg} \mathrm{C} \mathrm{m}^{-2} \mathrm{~d}^{-1}\right)$ to planktonic community respiration $\left(\mathrm{mg} \mathrm{C} \mathrm{m}^{-2} \mathrm{~d}^{-1}\right)$, i.e., $P / R$ ratio, versus integrated primary productivity $\left(\mathrm{mgCm}^{-2} \mathrm{~d}^{-1}\right)$ over euphotic zone. Values from meso- and oligotrophic systems are marked with solid $(\bigcirc)$ and open $(O)$ circles, respectively. Horizontal dashed line represents $P / R$ ratio equal to 1 .

integration primary productivity (Fig. $5 ; r^{2}=0.12$, $p=0.07)$.

\section{Discussion}

Even though both temperature and salinity in the ECS varies and deviates seasonally and spatially, a general year-round pattern of low temperature and salinity in the inner shelf and high temperature and salinity on the slope has been observed (Gong et al., 1996; Shiah et al., 1999; Tseng et al., 2000). Temporal and spatial variations of nutrient concentrations also have been found in the ECS. Corresponding to temperature and salinity distributions, a general trend in nutrient distribution is also observed in the ECS, i.e. high nutrient concentrations always are recorded in the inner shelf, and nutrients are usually depleted in surface slope waters except in the Kuroshio upwelling region off north east Taiwan (Liu et al., 1992; Gong et al., 1996, 2000). Similar general patterns in temperature, salinity and nutrient distributions are also evident in this study (Fig. 2).

Previous studies have suggested that riverine discharge from the China coast and upwelling of 
Kuroshio subsurface water were the two major nutrient sources into the ECS (Wong et al., 1998; Liu et al., 2000b). To understand these complicated shelf ecosystems, previous studies divided the ECS into separated regions according to their physical properties (Gong et al., 1996, 2000). Since biological activities are more directly associated with nutrients, the ECS was therefore categorized into mesotrophic and oligotrophic systems based on nutrient concentrations in this and previous studies (Shiah et al., 2001).

Seasonal and spatial variations in phytoplankton biomass and primary production have been reported in the ECS (Gong et al., 1996, 2000), and their study also found large spatial variations of Chl $a\left(1.5-74.4 \mathrm{mg} \mathrm{Chl} \mathrm{m}^{-2}\right)$ and primary production (16-854 $\mathrm{mg} \mathrm{C} \mathrm{m}^{-2} \mathrm{~d}^{-1}$ ) (Table 1). Averaged primary productivity is low in autumn $\left(341.3 \pm 234.6 \mathrm{mg} \mathrm{C} \mathrm{m}^{-2} \mathrm{~d}^{-1}\right)$ compared to the summer ( $>1000 \mathrm{mg} \mathrm{C} \mathrm{m}^{-2} \mathrm{~d}^{-1}$ in inner shelf; Shiah et al., 2001) in the same study area. To regulate phytoplankton growth in the ECS, nutrients and light (especially in the inner shelf) have been suggested as the two most important factors (Gong et al., 1996). Even though nutrient concentrations were significantly higher in mesotrophic than in oligotrophic system, no differences were evident in Chl $a$ values and primary production between these two systems (Fig. 2c, Table 1). Previous studies have suggested that growth of phytoplankton might be phosphate-limited in the ECS (Gong et al., 1996), But this seems not to be the case here since the measured ratio of inorganic nitrogen to phosphate (i.e., $N / P$ ratio; ca $17 \pm 8$ ) was close to the Redfield ratio (Shiah et al., 2001). This implies that growth of phytoplankton in the mesotrophic system might be limited by other factors. Even though no direct evidence indicates that light might be the regulating factor for phytoplankton growth in the mesotrophic system, light intensity is indeed lower in the autumn than in summer (Gong et al., 2003). In addition, light limitation can be indirectly supported by shallow euphotic zone (ca $27.3 \mathrm{~m}$ ) in the mesotrophic system, which was about $50 \%$ shallower than that in oligotrophic system (ca $49.5 \mathrm{~m}$; Table 1). In the oligotrophic system, growth of phytoplankton was likely controlled by nutrients, which were depleted in surface water in most regions of the ECS.

Planktonic community respiration (PCR) represents integrated carbon consumption by components including bacterioplankton, phytoplankton, planktonic protozoa, and zooplankton (Rowe et al., 1986; Hopkinson et al., 1989; Kemp et al., 1994; Liu et al., 2000a). Respiration rates ranged from $5.3-92.7 \mathrm{mg} \mathrm{C} \mathrm{m}^{-3} \mathrm{~d}^{-1}$ in this study, which are at the lower end of reported values of 3-647 $\mu \mathrm{g}$ $\mathrm{O}_{2} \mathrm{dm}^{-3} \mathrm{~d}^{-1}$ (i.e. $2.3-485.3 \mathrm{mg} \mathrm{C} \mathrm{m}^{-3} \mathrm{~d}^{-1}$ if assuming $R Q=1)$ from the coastal, shelf and slope regions (Williams, 1984; Biddanda et al., 1994). Previous studies have shown that PCR was positively correlated to primary production in some occasions in estuary or coastal regions (Jensen et al., 1990a; Smith and Kemp, 1995). There was, however, no significant relationship observed between PCR versus either Chl $a$ or primary production in this study, and similar results have been reported previously (e.g., Robinson and Williams, 1999). This suggests that PCR in the ECS was dominated by planktonic communities other than phytoplankton or was supported by other organic carbon sources rather than in situ primary production (Turner, 1978; Van Es, 1982).

Indeed, PCR was linearly regressed with protozoan biomass or multiple regressed with bacterial and protozoan biomass (Fig. 3a, Eq. (1)). This implies that organic carbon consumption by planktonic communities was more attributed to bacterial and protozoan communities. In aquatic ecosystems, it has been suggested that microbial communities, especially bacteria, play important roles in organic carbon consumption (Rowe et al., 1986; del Giorgio et al., 1997). Shiah et al. (2000a) estimated that heterotrophic bacteria completely consume biogenic particulate organic carbon in the ECS, and our results show that bacterioplankton account for a large fraction of PCR (Eq. 1). Even though bacterial respiration $\left(R_{\mathrm{B}}\right)$ was not measured directly, $R_{\mathrm{B}}$ can be estimated from bacterial production $\left(P_{\mathrm{B}}\right)$ and bacterial growth efficiency, which is equivalent to $\left(P_{\mathrm{B}} / R_{\mathrm{B}}+P_{\mathrm{B}}\right)$. A wide range of bacterial growth efficiency $(5 \%-$ $60 \%$; del Giorgio et al., 1997) has been reported, and it could vary along substrate gradient 
(Biddanda et al., 1994; del Giorgio et al., 1997). To estimate bacterial respiration, bacterial growth efficiency of $20 \%$ was assumed in this study. Estimated values of bacterial respiration contribute more than $39.2 \%$ of the PCR in the ECS, and this contribution fraction (i.e., 39.2\%) is within reported values from different shelves (Williams, 1984; Griffith et al., 1990; Chin-Leo and Benner, 1992). Even though bacterioplankton contributed a large fraction of PCR in this study, no significant correlation was observed between PCR versus biomass or production of bacterial community (Fig. 3b). Weak correlation between bacterial production and community respiration also has been found in other continental shelves (Chin-Leo and Benner, 1992; Biddanda et al., 1994). This implies that larger organisms, in addition to bacterioplankton, may play an important role in PCR in the ECS.

In aquatic ecosystems, planktonic protozoa also could serve as another important organic carbon consumer (Kemp et al., 1994). This also holds true in the ECS where a significant amount of PCR was contributed by the protozoan community (Fig. 3a, Eq. (1)), and this is especially obvious in regions with high respiration rates where protozoan biomass also peaked simultaneously (Table 1, Fig. 4). Carbon consumption rate for ciliates has been estimated and ranged within $28.8-67.2 \%$ of cell $\mathrm{Cd}^{-1}$ for hetero- and mixotrophic ciliates using single species measurement (Stoecker and Michaels, 1991). High respiration rate therefore, can be expected in regions with high protozoan biomass, and this was indeed observed in this study (Table 1, Fig. 4). Although protozoan biomass was about 10-fold different, ciliates dominated the mixotrophy found at stations located outside of the Yangtze River (i.e., Sts. $18,19,20,21$, and 22) in the mesotrophic system and at stations with high respiration rate in oligotrophic system (i.e., St. 14, 15, and 16) (data not shown). This implies that there must have been a large quantity of other substrates, in addition to bacterioplankton, to support high protozoan growth in the oligotrophic system.

All of this indicates that community respiration was dominated by both bacterial and protozoan communities in the ECS (Eq. (1)). To elucidate
Table 2

Relative contribution to planktonic community respiration by bacteria and protozoa in the mesotrophic (Meso) and oligotrophic (Oligo) systems in the ECS. Bacterial respiration $\left(R_{\mathrm{B}}\right)$ over $Z_{\mathrm{E}}$ was estimated using bacterial production $\left(P_{\mathrm{B}}\right.$; $\mathrm{mg} \mathrm{Cm}^{-3} \mathrm{~d}^{-1}$ ) and assuming $20 \%$ growth efficiency (del Giorgio et al., 1997) where bacterial growth efficiency is equivalent to $\left(P_{\mathrm{B}} / R_{\mathrm{B}}+P_{\mathrm{B}}\right)$. Respiration by protozoa $\left(R_{\mathrm{P}}\right)$ over $Z_{\mathrm{E}}$ was estimated using protozoan biomass $\left(\mathrm{mg} \mathrm{Cm}^{-3}\right)$ and assuming respiration rate of $45.6 \%$ of cell $\mathrm{Cd}^{-1}$ (i.e., average rate of heter- and mixotrophic ciliate from Stoecker and Michaels, 1991). Planktonic community respiration (PCR*; $\mathrm{mg} \mathrm{C} \mathrm{m}^{-3} \mathrm{~d}^{-1}$ ) was therefore estimated using $R_{\mathrm{B}}$ plus $R_{\mathrm{P}}$. Relative contribution of respiration by bacteria $\left(\% R_{\mathrm{B}}\right)$ and protozoa $\left(\% R_{\mathrm{P}}\right)$ were calculated using $R_{\mathrm{B}}$ or $R_{\mathrm{P}}$ divided by $\left(R_{\mathrm{B}}+R_{\mathrm{P}}\right)$, respectively. Planktonic community respiration (PCR; $\mathrm{mg} \mathrm{Cm}^{-3} \mathrm{~d}^{-1}$ ) measured from incubation was included for comparison

\begin{tabular}{lrcrrr}
\hline Regions & Sts & PCR & PCR* & $\% R_{\mathrm{B}}$ & $\% R_{\mathrm{P}}$ \\
\hline Meso & 2 & 5.3 & 8.1 & 55.8 & 44.2 \\
Meso & 3 & - & 5.1 & 96.6 & 3.4 \\
Meso & 4 & 82.9 & 112.9 & 99.9 & 0.1 \\
Meso & 6 & - & 40.3 & 99.0 & 1.0 \\
Meso & 7 & 22.0 & 8.3 & 44.0 & 56.0 \\
Meso & 8 & 51.8 & 16.0 & 18.5 & 81.5 \\
Meso & 18 & 38.3 & 30.1 & 92.7 & 7.3 \\
Meso & 19 & 14.2 & 20.3 & 90.7 & 9.3 \\
Meso & 20 & 23.9 & 17.3 & 66.8 & 33.2 \\
Meso & 21 & 39.0 & 17.8 & 43.8 & 56.2 \\
Meso & 22 & - & 18.5 & 85.0 & 15.0 \\
Oligo & 1 & 46.0 & 15.1 & 58.2 & 41.8 \\
Oligo & 9 & - & 40.1 & 8.9 & 91.1 \\
Oligo & 10 & 24.7 & 16.9 & 12.2 & 87.8 \\
Oligo & 14 & 92.7 & 71.7 & 5.8 & 94.2 \\
Oligo & 15 & 67.8 & 103.1 & 5.1 & 94.9 \\
Oligo & 16 & 75.5 & 97.8 & 5.9 & 94.1 \\
Oligo & 17 & 26.4 & 38.8 & 15.4 & 84.6 \\
Oligo & 23 & - & 35.2 & 9.7 & 90.3 \\
Oligo & 24 & - & 15.2 & 16.3 & 83.7 \\
\hline
\end{tabular}

(一) No data measured.

how components contributing to PCR varied in different trophic systems, relative contributions were estimated by assuming dominance by only bacterial and protozoan communities (Table 2). Results show no significant difference in measured PCR and estimated PCR $(p=0.24)$, and the relative difference i.e. (measured PCR-estimated $\mathrm{PCE}) /$ measured $\mathrm{PCR}^{*} 100 \%$ ) between measured and estimated PCR was only about $6.8 \% \pm 48.0 \%$ $($ mean \pm SD) (Table 2). This indicates that PCR in 
the ECS could be estimated reasonably from bacterial and protozoan communities. Results showed that bacteria contributed more than $72.1 \%$ of PCR, while respiration by protozoa represented less than $27.9 \%$ of PCR in the mesotrophic system (Table 2). Respiration dominated by the bacterial community has been observed in estuaries and coastal ecosystems (Griffith et al., 1990; Findlay et al., 1992; Kemp et al., 1994). Bacterial biomass and production (both expressed per $\mathrm{m}^{3}$ unit) were higher in the mesotrophic than in the oligotrophic system in this study, and similar results have been observed previously in the ECS (Shiah et al., 2000a). High bacterial respiration therefore can be expected in areas with high bacterial biomass and production. The opposite pattern was observed in the oligotrophic system where the protozoan community accounted for more than $84.7 \%$ of PCR, and the relative contribution could even reach $94.4 \%$ at stations with high respiration rates (Fig. 4, Table 2). Bacterial respiration was relatively unimportant in the oligotrophic system.

To explore whether the ecosystem is auto- or heterotrophic, the $P / R$ ratio was applied (Odum, 1956). Overall the ECS ecosystem was net heterotrophic during the study period, as evidenced by the small $P / R$ ratio (ca 0.33; Fig. 5). Between trophic systems, the mean value of $P / R$ ratio was slightly higher in mesotrophic than in oligotrophic systems, but not significantly different (Fig. 5). Several reasons might accounted for higher $P / R$ ratio in our case, it might be attributed mostly to the relatively lower respiration in the mesotrophic system. Since no significant difference in respiration rate $\left(\right.$ per $\mathrm{m}^{3}$ ) was evident between the two systems, lower integrated rates in the mesotrophic system was simply due to the rates integrated over shallower $Z_{\mathrm{E}}$ (Table 1). To support high respiration rate by organisms in a heterotrophic ecosystem, besides in situ carbon production, allochthonous organic carbon must be supplied either from outside of the system and/or resuspended or remobilized from superficial sedimentation. In the ECS, allochthonous DOC has been enriched by riverine discharge and remobilization of superficial sedimentation (Cauwet and Mack- enzie, 1993). It also has been observed that organic carbon is heavily subsidized from land and wetland ecosystems into coastal and shelf ecosystems (Hopkinson, 1985; Moran et al., 1991; Findlay et al., 1992). Even though there was no direct evidence to prove this hypothesis in this study, it could be indirectly supported by the low primary production and high bacterial production found in coastal regions (Table 1).

To support high bacterial metabolism in this low-productivity shelf, allochthonous organic carbon supplied from outside of the system is suggested. Based on chemical and physical properties (Fig. 2), it is likely that organic carbon from riverine input was the primary source. Previous studies also have shown that significant amounts of organic carbon are transported from Chinese rivers onto the shelf (Cauwet and Mackenzie, 1993; Chen and Wang, 1996). Resuspension of organic-rich sediment can be another extraneous carbon supply into the ECS water column. The ECS is a highly productive continental shelf, with an annual mean productivity of about $550 \mathrm{mg} \mathrm{C} \mathrm{m}^{-2} \mathrm{~d}^{-1}$ (Gong et al., 2000). Seasonally, primary productivity can reach more than $1000-1900 \mathrm{mg} \mathrm{C} \mathrm{m}^{-2} \mathrm{~d}^{-1}$ in the inner shelf ecosystem or within the upwelling region, especially during summer (Guo, 1991; Gong et al., 2000; Gong and Liu, 2003). Significant deposition of particulate organic carbon on superficial sedimentation has been found during blooms or highly productive periods in estuaries and coastal regions (Malone et al., 1988; Jensen et al., 1990b). In shallow aquatic ecosystems, forcing by strong physical events (e.g., monsoons, tropical depressions, and typhoons), organic-rich sediment can be easily re-suspended into the water column and utilized by organisms (Ritzrau and Graf, 1992; Dickey et al., 1998; Shiah et al., 2000b).

Although sedimentation rates in the ECS are high, the organic carbon content in the sedimentation was not as high as expected and varied between 0.3 and $0.6 \mathrm{wt} \%$ (Lin et al., 2000). Even though an important portion of the organic carbon in sediment was utilized either by sulfate reduction or burial, Lin et al. (2000) estimated that a significant fraction of the organic carbon was 
missing. Organic carbon resuspended from sediment and respired by planktonic communities therefore may serve as an important link for the missing carbon. Strong physical disturbance on the sediment surface could easily occur in the shallow continental shelf of ECS, which has water depth between 50 and $100 \mathrm{~m}$ (Wang et al., 2000). Resuspension of organic carbon from sediment is suggested by the high POC values observed in bottom water (data not shown). Strong resuspension might have been caused by super Typhoon Zeb, which passed along outer shelf of the ECS about 2 weeks prior to the study (http:// www.weather.unisys.com/hurricane/). That more than $50 \%$ of stations had MLD deeper than $70 \%$ of the water column depth can be evidenced as other persisting typhoon effect (Table 1). In addition, intrusion of the Kuroshio waters with high DOC concentrations may be another potential allochthonous source, although the magnitude varies temporally (Hung and Lin, 1995; Hung et al., 2000).

The low $P / R$ ratio suggests that continental shelf of the ECS was the main carbon source during the study periods (Fig. 4); however, it is difficult to predict or conclude whether the ECS is a net carbon sink or source based on a single survey. In coastal regions, a low $P / R$ ratio (i.e., $<1$ ) is usually observed in systems with low primary production (Duarte and Agustí, 1998 and their Fig. 3). In this study, low primary production was measured, with a mean value of $341.3 \mathrm{mg} \mathrm{C} \mathrm{m}^{-2} \mathrm{~d}^{-1}$ which was lower than the annual mean value (ca, $550 \mathrm{mg} \mathrm{C} \mathrm{m}^{-2} \mathrm{~d}^{-1}$; Gong et al., 2000). Based on air-sea difference of $f \mathrm{CO}_{2}$, several studies have concluded that the ECS is a $\mathrm{CO}_{2}$ sink, which is contrary with the present study (Peng et al., 1999; Tsunogai et al., 1999; Wang et al., 2000). Those studies were either conducted in the area north of the present study (Tsunogai et al., 1999; Wang et al., 2000) or in different seasons (Peng et al., 1999). Besides, high $f \mathrm{CO}_{2}$ value has been measured in the surface water in a limited area of the continental shelf, especially after a storm event (Tsunogai et al., 1999). Storm-induced and enhanced phytoplankton growth and/or primary production have been measured about week after events in or nearby the study area (Chang et al., 1996; Shiah et al., 2000b). Resuspension of organic-rich sediment and elevated bacterial growth rates also have been found after the passage of storms in various coastal zones (e.g., Ritzrau and Graf, 1992; Dickey et al., 1998). All this suggests that planktonic community respiration rate will be enhanced following high production, subsequent high growth rates of micro-organisms, and/or resuspension of organic-rich sediment induced by storm events. Typhoon Zeb passed along the outer shelf of the ECS about 2 weeks before the present study, which may explain why respiration rates, protozoan biomass, and POC concentrations were high, but primary productivity was relatively low (Table 1, Fig. 4). Episodic storm events therefore may have important impact on carbon consumption in shallow continental shelf, such as the ECS. To comprehensively understand carbon budget in the ECS, the impact and function of strong physical disturbances effect carbon consumption merit further study.

In summary, high bacterial biomass and production and low protozoan abundance were found in the mesotrophic part of the ECS. The opposite pattern was observed in oligotrophic system, which had low bacterial biomass and production and high protozoan abundance. Integrated respiration rates ranged from 127.6 to $4728.6 \mathrm{mg} \mathrm{C} \mathrm{m}^{-2} \mathrm{~d}^{-1}$, and respiration was linearly related to protozoan biomass or multiply regressed to both bacterial and protozoan biomasses. In the mesotrophic system, bacterial respiration accounted for more than $72.1 \%$ of PCR, whereas in the oligotrophic system, respiration was dominated by protozoa, contributing more than $84.7 \%$ to the total rates. Low ratio of $P / R$ (i.e., $<1$ ) suggested that the ECS was a net heterotrophic system. This implies that in situ organic carbon production could not sustain consumption by respiration. To support high rates of respiration, allochthonous organic carbon supplied from outside of this ecosystem is suggested. Allochthonous organic carbon supplied from riverine input along the China coast and resuspension of superficial sediment are two most potential sources. 


\section{Acknowledgements}

This research was supported by the National Science Council of the Republic of China under grant NSC-87-2811-M002-003 and NSC-91-2611M003-003-OP3. The work of C.-C. Chen was performed while the recipient of a grant from NSC, ROC (Grand no. NSC-88-2811-M0020033). We thank Y.-H. Wen, B.-W. Wang, and K.-J. Liu for assistance with the analyses of nutrients, Chl $a$ and primary productivity measurement. POC analysis was aided by Mr. J.-Y. Chen. Thanks also go to two anonymous reviewers for their valuable comments. We are also grateful to the officers and crew of the Ocean Researcher I for their assistance. This article is NCOR (National Center for Ocean Research, ROC) contribution \#43.

\section{References}

Biddanda, B., Opsahl, S., Benner, R., 1994. Plankton respiration and carbon flux through bacterioplankton on the Louisiana shelf. Limnology and Oceanography 39, 1259-1275.

Cauwet, G., Mackenzie, F.T., 1993. Carbon inputs and distribution in estuaries of turbid rivers: the Yangtze and Yellow rivers. Marine Chemistry 43, 235-246.

Chang, J., Chung, C.C., Gong, G.C., 1996. Influences of cyclones on chlorophyll-a concentration and Synechococcus abundance in a subtropical western Pacific coastal ecosystem. Marine Ecology Progress Series 140, 199-205.

Chen, C.T.A., Wang, S.L., 1996. Carbon and nutrient budgets on the East China Sea continental shelf. In: Tsunogai, S. (Ed.), Biogeochemical processes in the North Pacific, Proceedings of the International Marine Science Symposium. Mutsu, Japan, pp. 169-186.

Chin-Leo, G., Benner, R., 1992. Enhanced bacterioplankton production and respiration at intermediate salinities in the Mississippi River plume. Marine Ecology Progress Series 87, 87-103.

Cho, B.C, Azam, F., 1980. Major role of bacteria in biogeochemical fluxes in the ocean's interior. Nature 332, 441-443.

del Giorgio, P.A., Cole, J.J., Cimblerist, A., 1997. Respiration rates in bacteria exceed phytoplankton production in unproductive aquatic systems. Nature 385, 148-151.

Dickey, E.D., Chang, G.C., Agrawal, Y.C., Williams III, A.J., Hill, P.S., 1998. Sediment resuspension in the wakes of Hurricane Edouard and Hortense. Geophysical Research Letter 25, 3533-3536.
Duarte, C.M., Agustí, S., 1998. The $\mathrm{CO}_{2}$ balance of unproductive aquatic ecosystems. Science 281, 234-236.

Findlay, S., Pace, M.L., Lints, D., Howe, K., 1992. Bacterial metabolism of organic carbon in the tidal freshwater Hudson Estuary. Marine Ecology Progress Series 89, 147-153.

Fuhrman, J.A., Azam, F., 1982. Thymidine incorporation as a measurement of heterotrophic bacterioplankton production in marine surface waters: evaluation and field results. Marine Biology 66, 109-120.

Gaarder, T., Grann, H.H., 1927. Investigations of the production of plankton in the Oslo Fjord. Rapport et ProcesVerbaux des Reunions. Conseil Permanent International pour l'Exploration de la Mer 42, 3-31.

Gong, G.C., 1992. Chemical hydrography of the Kuroshio front in the sea northeast of Taiwan. Ph.D. Thesis, National Taiwan Univ., Taiwan, 204 pp.

Gong, G.C., Chen, Y.L., Liu, K.K., 1996. Chemical hydrography and chlorophyll $a$ distribution in the East China Sea in summer: implications in nutrient dynamics. Continental Shelf Research 16, 1561-1590.

Gong, G.C., Chang, J., Wen, W.H., 1999. Estimation of annual primary production in the Kuroshio waters northeast of Taiwan using a photosynthesis-irradiance model. Deep-Sea Research 46, 93-108.

Gong, G.C., Shiah, F.K., Liu, K.K., Wen, Y.H., Liang, M.H., 2000. Spatial and temporal variation of chlorophyll $a$, primary productivity and chemical hydrography in the southern East China Sea. Continental Shelf Research 20, 411-436.

Gong, G.C., Liu, G.J., 2003. Empirical primary production model for the East China Sea. Continental Shelf Research 23, 213-224.

Gong G. C., Wen, Y.H., Wang, B.W., Liu, G.J., 2003. Seasonal variation of chlorophyll a concentration, primary production and environmental conditions in the subtropical East China Sea. Deep-Sea Research II, this issue

Griffith, P.C., Douglas, D.J., Wainright, S.C., 1990. Metabolic activity of size-fractionated microbial plankton in estuarine, nearshore, and continental shelf waters of Georgia. Marine Ecology Progress Series 59, 263-270.

Guo, Y.J., 1991. The Kuroshio. Part II. Primary productivity and phytoplankton. Oceanography Marine Biological Annual Review 29, 155-189.

Hobbie, J.E., Daley, R.J., Jasper, S., 1977. Use of nucleopore filters for counting bacteria by fluorescence microscopy. Applied and Environmental Microbiology 33, 1225-1228.

Hopkinson, C.S., 1985. Shallow-water benthic and pelagic metabolism: evidence of heterotrophy in the nearshore Georgia Bight. Marine Biology 87, 19-32.

Hopkinson, C.S., Sherr, B., Wiebe, W.J., 1989. Size fractionated metabolism of coastal microbial plankton. Maine Ecology Progress Series 51, 155-166.

Hung, J.J., Lin, P.L., 1995. Distribution of dissolved organic carbon in the continental margin off northern Taiwan. Terrestrial, Atmospheric and Oceanic Sciences 6, 13-26. 
Hung, J.J., Lin, P.L., Liu, K.K., 2000. Dissolved and particulate organic carbon in the southern East China Sea. Continental Shelf Research 20, 545-569.

Jensen, L.M., Sand-Jenson, K., Marcher, S., Hansen, M., 1990a. Plankton community respiration along a nutrient gradient in a shallow Danish estuary. Marine Ecology Progress Series 61, 75-85.

Jensen, M.H., Lomstein, E., Sørensen, J., 1990b. Benthic $\mathrm{NH}_{4}^{+}$ and $\mathrm{NO}_{3}^{-}$flux following sedimentation of a spring phytoplankton bloom in Aarhus Bight, Denmark. Marine Ecology Progress Series 61, 87-96.

Kemp, P.F., Falkowski, P.G., Flagg, C.N., Phoel, W.C., Smith, S.L., Wallace, D.W.R., Wirick, C.D., 1994. Modeling vertical oxygen and carbon flux during stratified spring and summer conditions on the continental shelf, Middle Atlantic Bight, eastern USA. Deep Sea Research II 41, 629-655.

Lee, S., Fuhrman, J.A., 1987. Relationships between biovolume and biomass of naturally derived marine bacterioplankton. Applied and Environmental Microbiology 53, 1298-1303.

Levitus, S., 1982. Climatological atlas of the world ocean, NOAA Prof. Pap. 13, 173 pp., US Gov. Print. Off., Washington, D.C.

Lin, S., Huang, K.M., Chen, S.K., 2000. Organic carbon deposition and its control on iron sulfide formation of the southern East China Sea continental shelf sediments. Continental Shelf Research 20, 619-635.

Liu, K.K., Gong, G.C., Lin, S., Shyu, C.Z., Pai, S.C., Wei, C.L., Chao, S.Y., 1992. Response of the Kuroshio upwelling to the onset of northeast monsoon in the sea north of Taiwan: observations and a numerical simulation. Journal of Geophysical Research 97, 12511-12526.

Liu, K.K., Iseki, K., Chao, S.Y., 2000a. Continental margin carbon fluxes. In: Hanson, R.B., Ducklow, H.W., Field, J.G. (Eds.), The changing ocean carbon cycle: A midterm synthesis of the Joint Global Ocean Flux Study. Cambridge University Press, Cambridge, pp. 187-239.

Liu, K.K., Tang, T.Y., Gong, G.C., Chen, L.Y., Shiah, F.K., 2000b. Cross-shelf and along-shelf nutrient fluxes derived from flow fields and chemical hydrography observed in the southern East China Sea off northern Taiwan. Continental Shelf Research 20, 493-523.

Malone, T.C., Crocker, L.H., Pike, S.E., Wendler, B.W., 1988. Influences of river flow on the dynamics of phytoplankton production in a partially stratified estuary. Marine Ecology Progress Series 48, 235-249.

Moran, M.A., Pomeroy, L.R., Sheppard, E.S., Atkinson, L.P., Hodson, R.E., 1991. Distribution of terrestrially dissolved organic matter on the southeastern US continental shelf. Limnology and Oceanography 36, 1134-1149.

Odum, H.T., 1956. Primary production in flowing waters. Limnology and Oceanography 1, 102-117.

Pai, S.C., Gong, G.C., Liu, K.K., 1993. Determination of dissolved oxygen in seawater by direct spectrophotometry of total iodine. Marine Chemistry 41, 343-351.
Parsons, T.R., Maita, Y., Lalli, C.M., 1984. A Manual of Chemical and Biological Methods for Seawater Analysis. Pergamon Press, New York, pp. 173.

Peng, T.H., Hung, J.-J., Wanninkhof, R., Millero, F.J., 1999. Carbon budget in the East China Sea in spring. Tellus 51B, 531-540.

Putt, M., Stoecker, D.K., 1989. An experimentally determined carbon: volume ratio for marine "oligotrichous" ciliates from estuarine and coastal waters. Limnology and Oceanography 34, 1097-1107.

Ritzrau, W., Graf, G., 1992. Increase of microbial biomass in the benthic turbidity zone of Kiel Bight after resuspension by a storm event. Limnology and Oceanography 37 (5), 1081-1086.

Robinson, C., Williams, P.J.leB., 1999. Plankton net community production and dark respiration in the Arabian Sea during September 1994. Deep-Sea Research II 46, 745-765.

Rowe, G.T., Smith, S., Falkowski, P., Whitledge, T., Theroux, R., Phoel, W., Ducklow, H., 1986. Do continental shelves export organic matter? Nature 324, 559-561.

Shiah, F.K., Gong, G.C., Liu, K.K., 1999. Temperature vs. substrate limitation of heterotrophic bacterioplankton production across trophic and temperature gradients in the East China Sea. Aquatic Microbial Ecology 17, 247-254.

Shiah, F.K., Liu, K.K., Kao, S.J., Gong, G.C., 2000a. The coupling of bacterial production and hydrography in the southern East China Sea. Continental Shelf Research 20, 459-477.

Shiah, F.K., Chung, S.W., Kao, S.J., Gong, G.C., Liu, K.K., 2000b. Biological and hydrographical responses to tropical cyclone (typhoons) in the continental shelf of the Taiwan Strait. Continental Shelf Research 20, 2029-2044.

Shiah, F.K., Chen, T.Y., Gong, G.C., Chen, C.C., Chiang, K.P., Hung, J.J., 2001. Differential coupling of bacterial and primary production in mesotrophic and oligotrophic systems of the East China Sea. Aquatic Microbial Ecology 23, 273-282.

Siegenthaler, U., Sarmiento, J.L., 1993. Atmospheric carbon dioxide and the ocean. Nature 365, 119-125.

Stoecker, D.K., Michaels, A.E., 1991. Respiration, photosynthesis and carbon metabolism in planktonic ciliates. Marine Biology 108, 441-447.

Strickland, J.D.H., Parsons, T.R., 1972. A practical handbook of seawater analysis. Fisheries Research Board of Canada, Ottawa, Canada, 310 pp.

Smith, E.M., Kemp, W.M., 1995. Seasonal and regional variations in plankton community respiration for Chesapeake Bay. Marine Ecology Progress Series 116, 217-231.

Tseng, C., Lin, C., Chen, S., Shyu, C., 2000. Temporal and spatial variations of sea surface temperature in the East China Sea. Continental Shelf Research 20, 373-387.

Tsunogai, S., Watanabe, S., Sato, T., 1999. Is there a "continental shelf pump" for the absorption of atmospheric $\mathrm{CO}_{2}$ ? Tellus $51 \mathrm{~B}, 701-712$. 
Turner, R.E., 1978. Community plankton respiration in a salt marsh estuary and the importance of macrophytic leachates. Limnology and Oceanography 23, 442-451.

Van Es, F.B., 1982. Community metabolism of intertidal flats in the Ems-Dollard estuary. Marine Biology 66, 95-108.

Walsh, J.J., 1991. Importance of continental margins in the marine biogeochemical cycling of carbon and nitrogen. Nature 350, 53-55.

Wang, S.L., Chen, C.T.A., Hong, G.H., Chung, C.S., 2000. Carbon dioxide and related parameters in the East China Sea. Continental Shelf Research 20, 525-544.
Williams, P.J.leB., 1984. A review of measurements of respiration rates of marine plankton population. In: Hobbie, J.E., Williams, P.J.leB. (Eds.), Heterotrophic activity in the sea. Plenum Press, New York, pp. 357-389.

Wong, G.T.F., Gong, G.C., Liu, K.K., Pai, S.C., 1998. 'Excess Nitrate' in the East China Sea. Estuarine. Coastal and Shelf Science 46, 411-418.

Wong, G.T.F., Chao, S.Y., Li, Y.H., Shiah, F.K., 2000. The Kuroshio edge exchange processes (KEEP) study-an introduction to hypotheses and highlights. Continental Shelf Research 20, 335-347. 